\title{
CHEMOSPHERE
}

\section{Relationship between the extractable metals from soils and metals taken up by maize roots and shoots}

\author{
Wei-Sheng Wang, Xiao-Quan Shan *, Bei Wen, Shu-Zhen Zhang \\ Research Center for Eco-Environmental Sciences, Chinese Academy of Sciences, P.O. Box 2871, Beijing 100085, China
}

Received 6 November 2002; received in revised form 16 April 2003; accepted 21 April 2003

\begin{abstract}
Two extraction procedures, i.e. a single extraction procedure using low-molecular-weight-organic-acids (LMWOAs) as extractant and a sequential extraction procedure recommended by the European Community Bureau of Reference (BCR), were performed to extract metal fractions from wet rhizosphere soil. And the extracted soil solutions were further fractionated as colloidal and truly dissolved fractions. Heavy metals in maize roots were experimentally defined as metals adsorbed on cell wall and metals taken up by cross-membrane by washing with $\mathrm{CaCl}_{2}$. The correlation coefficients between extractable metals from soil and taken up by maize roots and shoots were compared between two extraction methods, and a good correlation was obtained if LMWOAs were used. In contrast, the correlation coefficients were poor when the BCR method was used.
\end{abstract}

(C) 2003 Elsevier Ltd. All rights reserved.

Keywords: Heavy metals; Bioavailability; Extraction; Single regression

\section{Introduction}

It is common conception nowadays that the total concentrations of metals in soils are not a good indicator of bioavailability, or a good tool for potential risk assessment either, due to the different and complex distribution patterns of metals among various chemical species or solid phases (Chen et al., 1996). In recent years, the experimentally defined chemical fractionation procedures have been applied to identify plant-available forms of trace metals in soils. There were a variety of reports on the single and/or sequential extraction procedures for available metals in the literatures (Novozamsky et al., 1993; Houba et al., 1996; McGrath, 1996; Kennedy et al., 1997; Maiz et al., 1997; Krishnamurti and Naidu, 2002). Among these methods, the most widely used procedures were those recommended by

\footnotetext{
* Corresponding author. Tel.: +86-10-6292-3560; fax: +86-106292-3563.

E-mail address: xiaoquan@mail.rcees.ac.cn (X.-Q. Shan).
}

Tessier et al. (1979) and European Community Bureau of Reference (BCR), now the Standard Measurements and Testing Programme of the European Community (Ure et al., 1993). These extraction procedures have been used to partition metals into fractions defined as water soluble, exchangeable and carbonate bound (fraction $\mathrm{B} 1$ ), $\mathrm{Fe}-\mathrm{Mn}$ oxide bound (fraction B2), organic materials and sulfide bond (fraction B3). However, sequential extraction methods were suffered from nonselectivity of extractants and trace element redistribution among phases during the extraction processes (Shan and Chen, 1993; Tu et al., 1994; Howard and VandenBrink, 1999). To date, no methods have been considered as universally applicable for the assessment of metal fractions in soils and plant bioavailability. Most of data derived from bioavailability studies tend to be inconsistent, making interpretations difficult (Davies, 1992; Qian et al., 1996; Sauvé et al., 1996). The reasons for this fact are that metal bioavailability depends on many factors such as plant species and soil properties. Different fractions of soil metals vary considerably in their chemical reactivity and bioavailability (Qian et al., 1996; Li et al., 1998; 
Zhang et al., 2000; Wang et al., 2001). In addition, the present approach for bioavailability prediction does not take into account the real chemical speciation of metals in soils and uptake mechanisms of metals by plants either. The main reasons for this are the inherent difficulties in obtaining the detailed information on the biological active speciation of metals in soils and uptake through biological membrane of plants. Considering this situation one can understand why there are no universally experimental methods available for prediction of bioavailability of metals in soils in the literature (Sauvé et al., 2000). To obtain practical goal, appropriate computational written programs and laboratory or field analytical techniques need to be developed along this direction of establishing the relationship between the chemical metals speciation in soils and uptake routes by plants in the future.

The alternative way to predict the bioavailability of metals in soils is to simulate the real field conditions, under which the plants grow on soils. It seems that the most promising empirical approach nowadays was the effective soil solution concentration (Zhang et al., 2001). It took into account not only the diffusional and convective transport of solutes to plant roots, but also the resupply of metal solutes from solid phase under the deficiency conditions. However, this method could only be used for soils of its moist content at or above $80 \%$. More serious drawback of the method is that the soil solutes were taken from bulk soil surface rather than from rhizosphere soils, indicating the empirical conditions are still far away from the real field conditions.

It is generally recognized that rhizosphere is distinguished from bulk soil by the root influences (Anderson et al., 1993). It is a zone of increased microbial activity and low-molecular-weight-organic-acids (LMWOAs). According to the current knowledge LMWOAs play an important role not only in carbon metabolism but also in root-soil interactions (Jones, 1998; López-Bucio et al., 2000). Unfortunately, no one considers the importance of rhizosphere zone in establishing correlation of metal fractions in soils and plant availability. It must be pointed out that many factors can influence metal fraction and bioavailability such as interactions with physicochemical properties of soils, and genotype differences of plants, etc. Therefore, the use of bulk soils in the soil testing purposes such as bioavailability prediction is problematic. The importance of using rhizosphere wet soil in bioavailability is addressed in our previous reports (Wang et al., 2001).

Another important reason related with the uncertainty of predicting bioavailability may be the sampling strategies. Sampling of plants may introduce the highest errors in the final results (Markert, 1993; Kovacheva et al., 2000). Unfortunately, a difficult matter is the quantitative removal of fine soil grain from root surface, which may introduce $100-300 \%$ error in the final results
(Markert, 1996, Kovacheva et al., 2000). The effect of washing process on bioavailability needs to be examined.

In time-dependent kinetic studies of root metal absorption in plants, an initial rapid accumulation was observed, followed by a slower linear phase of accumulation (Maria and Cogliatti, 1988; Zhang and Taylor, 1989; Lasat et al., 1996). It was suggested that the initial phase represented rapid binding to the cell walls and that the subsequent slower phase was due to transport across the plasma membrane into the cytoplasm. So separation of the root metals into these two compartments for the test of bioavailability may be worthwhile.

Of course, the prerequisite for promising bioavailability approach is to simulate the real-world field conditions, under which plants grow on soils. In our previous studies the use of rhizosphere wet soils and LMWOAs as extractant for available labile soil solution fractions were strongly recommended (Zhang et al., 2000; Shan et al., 2003). The aims of the present study are to examine: (1) Does the washing of plant roots affect the bioavailability? (2) Does the cell wall adsorption or cross-membrane uptake of metals in plant roots determine the bioavailability? (3) Is the experimentally defined total colloidal soil fraction or truly dissolved fraction more available by plants?

\section{Materials and methods}

\subsection{Soils}

Soil samples were collected from 15 rural areas around China, represented typical Chinese soils with different physical and chemical properties. All soils were taken from the surface layer $(0-20 \mathrm{~cm})$ of cultivated soils. The air-dried soils were fertilized to $0.4 \mathrm{~g} \mathrm{~N}$ and $\mathrm{P} / \mathrm{kg}$ soil with solution of $\mathrm{KH}_{2} \mathrm{PO}_{4}$ and $\left(\mathrm{NH}_{4}\right)_{2} \mathrm{CO}_{3}$. After the soil and solution were mixed thoroughly, the soils were air-dried again, ground and sieved to pass through a 1 $\mathrm{mm}$ plastic mesh for further use. Precautions were taken to avoid contamination during sampling, drying, grinding and storage. Soil properties of $\mathrm{pH}$, organic matter (OM) and cation exchange capacity (CEC) were determined using standard methods (Lao, 1988). These soil properties are given in Table 1.

\subsection{Greenhouse experiment}

A homemade rhizobox (Wang et al., 2001) was used to plant maize. The dimension of the rhizobox was $120 \times 100 \times 150(\mathrm{~mm}$, length $\times$ width $\times$ height $)$. The rhizobox was divided into three sections: a central zone or rhizosphere zone (20 $\mathrm{mm}$ in width), which was surround by nylon cloth ( $300 \mathrm{mesh})$, and left and right nonrhizosphere zones $(50 \mathrm{~mm}$ in width). To each rhizobox was 
Table 1

Selected properties of soils

\begin{tabular}{lllll}
\hline Sample & Site & $\mathrm{pH}$ & CEC $\left(\mathrm{cmol} \mathrm{kg}^{-1}\right)$ & OM $(\%)$ \\
\hline 1 & Jiamusi & 5.32 & 27.03 & 4.30 \\
2 & Yuxi & 6.05 & 25.78 & 1.37 \\
3 & Kunming & 4.71 & 26.74 & 4.22 \\
4 & Shandjong & 5.76 & 30.20 & 3.62 \\
5 & Jiangxi & 5.49 & 14.24 & 3.53 \\
6 & Shanghai & 7.62 & 36.65 & 3.28 \\
7 & Hangzhu & 6.90 & 19.76 & 2.09 \\
8 & Hefei & 5.58 & 24.95 & 2.37 \\
9 & Wuhan & 6.65 & 53.98 & 2.28 \\
10 & Changsha & 5.20 & 43.11 & 1.37 \\
11 & Dongguan & 7.13 & 15.92 & 2.99 \\
12 & Beijing & 7.83 & 14.1 & 2.10 \\
13 & Ankang & 7.30 & 14.4 & 3.14 \\
15 & Chaozhou & 5.69 & 14.1 & 2.46 \\
\hline
\end{tabular}

added $1.5 \mathrm{~kg}$ of the treated soil. The maize used for washing was planted in plastic pots $(20 \times 18 \mathrm{~cm}$, inner diameter $\times$ height). The soil was collected from Beijing.

Maize seeds (Zea Mays) were thoroughly rinsed with water, and germinated on a filter paper. After the maize seeds were germinated for $36 \mathrm{~h}$ at $20{ }^{\circ} \mathrm{C}$ in the dark, uniformly germinated seeds with radical emerged were sown in the soil. The relative humidity of soils was kept around $15 \%$ by adding deionized water daily. The maize was harvested 8 weeks after planting. The rhizosphere and nonrhizosphere soils were collected and kept in refrigerator $\left(-18^{\circ} \mathrm{C}\right)$ for further use in the remainder of the study.

\subsection{Washing procedure of maize roots}

The living maize roots were first washed thoroughly with tap water to remove soil adhered to roots. Then, the roots were washed with ultrasound-assisted bath at $35 \mathrm{~W}, 25 \mathrm{kHz}$ for various periods. After ultrasoundassisted washing the roots were washed with different concentrations of $\mathrm{CaCl}_{2}$ solution. Among the reagents used for root washing, $\mathrm{CaCl}_{2}$ was often used (Lasat et al., 1996), different concentrations of $\mathrm{CaCl}_{2}$ solution in $5.0 \mathrm{mmoll}^{-1}$ Mes-Tris solution, $\mathrm{pH}$ 6.0, for different washing periods at $0{ }^{\circ} \mathrm{C}$ in ice bath were examined. Afterwards, the roots were washed three times with deioned water to remove $\mathrm{Ca}^{2+}$. Finally, the roots were then cut down from the shoots and dried to constant weight at $65{ }^{\circ} \mathrm{C}$ for $36 \mathrm{~h}$ for the determination of heavy metals. The maize shoots were thoroughly washed with tap water and then washed with deioned water. Then, the shoots were dried to constant weight in oven at $65^{\circ} \mathrm{C}$ for $36 \mathrm{~h}$ for further use.

\subsection{Fractionation of metals in soil}

Two extraction procedures were compared. The first two steps of BCR method and a single extraction procedure were adopted in this study. Among the reported LMWOAs, acetic acid, formic acid, citric acid and malic acids were frequently found to be the abundant organic acids (Jones, 1998; Li et al., 2003). The detailed extraction conditions are listed in Table 2. After extraction, the extractant was centrifuged at $4000 \mathrm{~g}$ for $30 \mathrm{~min}$. Then, the supernatant was filtrated through $0.45 \mu \mathrm{m}$ cellulose acetate membrane, which was referred to total colloidal fraction. For the BCR procedure, heavy metals in the filtrate were directly determined. For the LMWOAs extraction procedure, the filtrate was successively ultrafiltered through molecular weight cutoff of $1 \mathrm{kD}$ membrane. The fraction obtained by ultrafiltrating through $1 \mathrm{kD}$ membrane was referred to the truly dissolved fraction. The concentrations of heavy metals in each fraction were determined. All samples were performed duplicated except four repeated experiments were performed for washing procedure.

\subsection{Digestion of plant tissues}

The maize root and leaf samples were digested with $2 \mathrm{ml} \mathrm{HNO}_{3}-\mathrm{HClO}_{4}(1: 1, \mathrm{v} / \mathrm{v})$ under high pressure condition, and the detailed experimental conditions were given previous (Zhang and Shan, 1997).

\subsection{Determination of heavy metals}

All reagents used were of analytical grade or better. Stock solutions of each metal for sample analysis, 1000 $\mathrm{mgl}^{-1}$, were obtained from Research Center for Chinese 
Table 2

The extraction procedures adopted in this experiment

\begin{tabular}{llll}
\hline Procedure & Extractant & $\begin{array}{l}\text { Volume } \\
(\mathrm{ml})\end{array}$ & Extraction condition \\
\hline First step of BCR (B1 fraction) & $0.11 \mathrm{moll}^{-1} \mathrm{CH}_{3} \mathrm{COOH}$ & 20 & $\begin{array}{l}0.60 \mathrm{~g} \text { wet soil, shaking 16 h, at room } \\
\text { temperature } \\
\end{array}$ \\
Second step of BCR (B2 fraction) & $0.1 \mathrm{moll}^{-1} \mathrm{NH}_{2} \mathrm{OH} \cdot \mathrm{HCl}^{\mathrm{a}}$ & 20 & $\begin{array}{l}0.60 \mathrm{~g} \text { wet soil, shaking } 16 \mathrm{~h} \text {, at room } \\
\text { temperature }\end{array}$ \\
Single extraction & $10 \mathrm{mmoll}^{-1}$ mixed organic acid & 30 & $\begin{array}{l}6.60 \text { g wet soil, shaking } 12 \mathrm{~h}, \text { at room } \\
\text { temperature }\end{array}$ \\
\hline
\end{tabular}

${ }^{\mathrm{a}} \mathrm{pH}$ was adjusted to 2.0 by $0.1 \mathrm{moll}^{-1} \mathrm{HNO}_{3}$.

${ }^{\mathrm{b}}$ Acetic acid:formic acid:citric acid:malic acid $=2: 2: 1: 1$ (molar ratio), its $\mathrm{pH}$ values were adjusted with dilute $\mathrm{HNO}_{3}$ or $\mathrm{NaOH}$ to the soil $\mathrm{pH}$.

Standard Materials. High purity of water $(18 \mathrm{M} \Omega \mathrm{cm})$ was prepared by double distillation of deionized water in a fused quartz still (Westdeutsche Quarzschmelze, Geesthacht Germany). Nitric acid was purified by subboiling distillation in quartz still using ultrapure grade $\mathrm{HNO}_{3}$ as feed. Prior to use, all beakers, calibrated flasks and other glassware cleaned sequentially with tap water, neutral detergent, tap water, then in nitric acid $(1+1)$ for $48 \mathrm{~h}$ and cleaned with double distilled deionized water before use.

Total concentrations of heavy metals $\mathrm{Cr}$, Co, Mo, $\mathrm{Ni}, \mathrm{Zn}, \mathrm{Cu}, \mathrm{Cd}$ and $\mathrm{Pb}$ in various soil colloid-size fractions and maize samples were determined by inductively coupled plasma mass spectrometry (VG PlasmaQuard 3, Fisons Instruments, UK). The operating conditions for the determinations were optimized. ${ }^{115} \mathrm{In}$ at $10 \mathrm{ng} \mathrm{ml}^{-1}$ in $2 \%$ nitric acid was used as an internal standard to compensate for matrix suppression and signal drifting during analysis.

\section{Results and discussion}

\subsection{Ultrasound-assisted washing of maize roots}

After the maize roots were thoroughly washed with tap water followed by deionized water for several times, the maize roots were put into beakers containing deionized water for ultrasound-assisted washing under the conditions described in the experimental section. The effect of washing time on the removal of fine soil grains from the roots is schematically shown in Fig. 1, where $\mathrm{Zn}, \mathrm{Cu}$ and $\mathrm{Pb}$ were selected as typical metals. The results showed that the concentrations of heavy metals in roots remained almost unchanged over the washing periods of $0-60 \mathrm{~min}$. Based on this finding one may conclude that the washing by tap water followed by deionized water was effective to remove the soil grains adhered to maize roots, and the ultrasound-assisted washing could hardly improve washing further. So in the

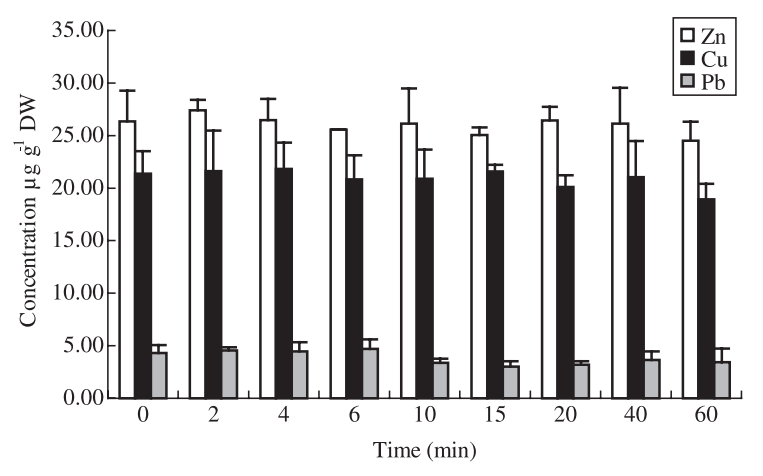

Fig. 1. Relationship between the heavy metals in maize roots and ultrasound-assisted washing. Results are expressed as the mean \pm S.D. $(n=4)$.

remainder of the experiments, no ultrasound-assisted washing was adopted.

\subsection{Optimization of $\mathrm{CaCl}_{2}$ washing to distinguish cell wall adsorption from cross-membrane uptake}

The effect of $\mathrm{CaCl}_{2}$ washing with different concentrations of $\mathrm{CaCl}_{2}$ in $5.0 \mathrm{mmoll}^{-1}$ Mes-Tris buffer, $\mathrm{pH}$ 6.0 on the concentrations of heavy metals in roots is shown in Fig. 2. In order to see it more clearly only $\mathrm{Zn}$, $\mathrm{Cu}$ and $\mathrm{Pb}$ were chosen as the representative of heavy metals. As it can be seen quite clearly that the concentration of heavy metals in maize roots decreased rapidly when the concentration of $\mathrm{CaCl}_{2}$ increased from 0 to 0.5 $\mathrm{mmoll}^{-1}$ and then almost remained unchanged over the concentration range of $\mathrm{CaCl}_{2}$ from 0.5 to $5.0 \mathrm{mmoll}^{-1}$. However, $\mathrm{Zn}, \mathrm{Cu}$ and $\mathrm{Ni}$ in maize root gradually decreased again when the concentration of $\mathrm{CaCl}_{2}$ was further increased from 5.0 to $10 \mathrm{mmoll}^{-1}$. Based on the above study, the $\mathrm{CaCl}_{2}$ concentration of $1.0 \mathrm{mmoll}^{-1}$ was used in the remainder of the present study. Hereafter, the metals washed away with the concentration of $0.5 \mathrm{mmoll}^{-1} \mathrm{CaCl}_{2}$ were referred as cell wall adsorption, 


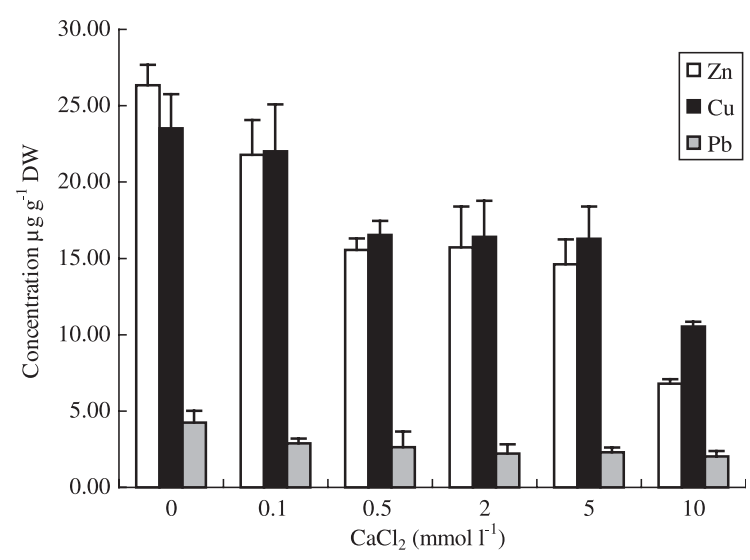

Fig. 2. Effect of $\mathrm{CaCl}_{2}$ concentration on metal desorption from roots. Results are expressed as the mean \pm S.D. $(n=4)$.

and the metals remained after $\mathrm{CaCl}_{2}$ washing were designated as cross-membrane uptake. Quite similar phenomenon was reported in the literature (Maria and Cogliatti, 1988; Zhang and Taylor, 1989; Lasat et al., 1996). It was suggested that the initial phase represented rapid entry into root-free space and binding to the cell walls and the subsequent slower phase was due to transport across the plasma membrane into the cytoplasm (Maria and Cogliatti, 1988). The metals by cell wall adsorption and cross-membrane uptake were separately correlated with metal fractions in soil in the remainder of the study.

\subsection{The optimization of washing time}

The maize root was washed with $1.0 \mathrm{mmoll}^{-1} \mathrm{CaCl}_{2}$ solution in $5.0 \mathrm{mmoll}^{-1}$ Mes-Tris buffer, $\mathrm{pH}$ 6.0, for different periods, and the washing time was optimized and the results are shown in Fig. 3, where only $\mathrm{Zn}, \mathrm{Cu}$ and $\mathrm{Pb}$ were shown there. A rapid decrease of metals in roots was observed in the first $6 \mathrm{~min}$ followed by an

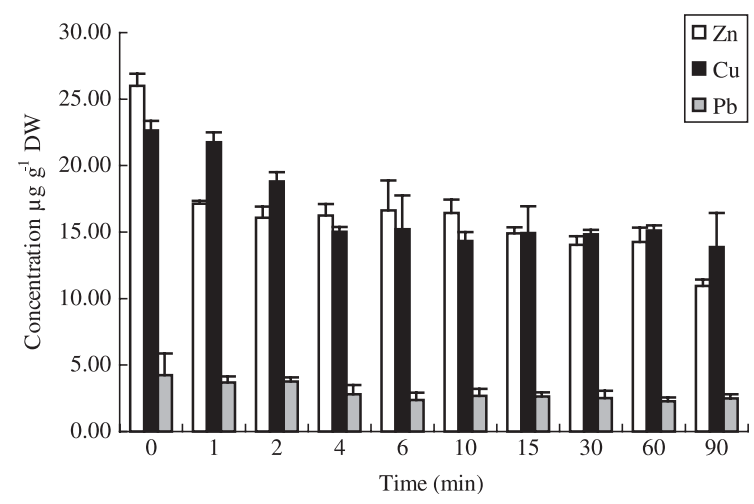

Fig. 3. Effect of $\mathrm{CaCl}_{2}$ washing time on metal desorption from roots. Results are expressed as the mean \pm S.D. $(n=4)$. unchanged profile up to washing time of $60 \mathrm{~min}$. And the rapid decrease profile may correspond to heavy meals adsorbed by cell wall of plant roots, the unchanged profile may mean that heavy metals entered cell membrane and difficult to be washed down. Considering little change in heavy metals in the maize roots over the washing time range of 15-60 min, the washing time of 30 min was adopted.

\subsection{Heavy metal concentrations in B1 and B2 fractions}

For a comparison, the sequential extraction procedure was also adopted and fraction B1 (water soluble, exchangeable and carbonate bound) and fraction B2 (Fe-Mn oxides bound) were also determined. The concentrations of different heavy metals in fraction B2 were similar or higher than those in fraction B1 except for the concentration of $\mathrm{Cr}$ (data not shown).

\subsection{Partitioning of heavy metals among soil colloid-size fractions}

Traditionally, filtration is performed with a pore size of $0.45 \mu \mathrm{m}$ membrane. However, this filtrate always includes colloidal fraction and truly dissolved metals. In order to determine the concentrations of truly dissolved metals, a home-made ultrafiltration device using a pore size of molecular weight cutoff of $1 \mathrm{kD}$ membrane was used to separate truly dissolved fraction from soil colloidal fraction through $0.45 \mu \mathrm{m}$ membrane. Hereafter, the fractions through $0.45 \mu \mathrm{m}$ and $1 \mathrm{kD}$ membrane filtration were referred as soil colloidal fraction and truly dissolved fraction. It was demonstrated that the concentrations of heavy metals in soil colloid fraction were higher than that in truly dissolved fraction when LMWOAs were used (data not shown). If the concentrations of metals in soil colloid fraction were normalized as $100 \%$, the metal concentrations in truly dissolved fraction were about $72.4 \%, 68.4 \%, 78.1 \%, 66.3 \%, 40.6 \%$, $79.5 \%, 83.4 \%$ and $52.0 \%$ for $\mathrm{Cr}, \mathrm{Co}, \mathrm{Ni}, \mathrm{Zn}, \mathrm{Cu}, \mathrm{Mo}, \mathrm{Cd}$ and $\mathrm{Pb}$, respectively. Seven metals $\mathrm{Cr}, \mathrm{Co}, \mathrm{Ni}, \mathrm{Zn}, \mathrm{Mo}$, $\mathrm{Cd}$ and $\mathrm{Pb}$ ) were mainly present in the truly dissolved fraction, it may mean that: (1) LMWOAs excreted by plants could transport metals from other forms into truly dissolved form by complexing process, (2) metals in the truly dissolved fraction may be easily available by plants. And for metals in B1 fraction, they were not fractionated into colloidal and truly dissolved fraction. The reasons are that: (1) our early studies showed that heavy metals were mostly existed in the truly dissolved fraction when the first step of BCR procedure was used, (2) the $\mathrm{pH}$ of the extractant of the first step of BCR procedure were about 2.0 , which is nearly to the lower $\mathrm{pH}$ limit of the membrane, and it may introduce large error. An across analysis indicated that the extractable heavy metals in $\mathrm{B} 1$ fraction were much higher than that 
obtained by LMWOAs, and these may be attributed to higher concentration of acetic acid used in the first step of BCR method.

\subsection{Heavy metal concentrations in cell wall and cell membrane of maize roots}

If the concentrations of heavy metals in intact roots were normalized as $100 \%$, the concentrations of metals of cross-membrane uptake were about $70.6 \%, 66.7 \%$, $76.1 \%, 77.4 \%, 83.2 \%, 80.1 \%, 77.0 \%$ and $62.7 \%$ for $\mathrm{Cr}$, $\mathrm{Co}, \mathrm{Ni}, \mathrm{Zn}, \mathrm{Cu}, \mathrm{Mo}, \mathrm{Cd}$ and $\mathrm{Pb}$, respectively. And the concentrations of metals adsorption on cell wall were about $29.4 \%, 33.3 \%, 23.9 \%, 22.6 \%, 16.8 \%, 19.9 \%, 33 \%$ and $37.3 \%$ for $\mathrm{Cr}, \mathrm{Co}, \mathrm{Ni}, \mathrm{Zn}, \mathrm{Cu}, \mathrm{Mo}, \mathrm{Cd}$ and $\mathrm{Pb}$, respectively. The results may suggest that heavy metals in roots mainly enter root cell membrane. The similar distribution of heavy metals among cell wall and cross- membrane indicates that plant genotype dominantly determines the uptake of heavy metals.

\subsection{Comparison of bioavailability between heavy metals in cell wall adsorption, cross-membrane uptake and total concentration in intact maize roots}

A simple regression was used for the bioavailability correlation analysis of heavy metals in root cell wall, membrane uptake and total concentration in intact maize roots with soil fractions obtained by single extraction with LMWOAs and BCR's method. The correlation coefficients are given in Tables 3 and 4 .

As it can be seen clearly from Table 3 that the correlation coefficients between the concentration of heavy metals in cell wall, cross-membrane and intact roots and that in soil colloid fraction and truly dissolved fraction were quite good, and there were insignificant differences

Table 3

Correlation coefficients $(R)$ of heavy metals in soil fractions $(n=15)$ with that in plant roots using 10 mmoll $^{-1}$ LMWOAs as extractant

\begin{tabular}{|c|c|c|c|c|c|c|}
\hline & \multicolumn{3}{|c|}{ Soil colloidal fraction } & \multicolumn{3}{|c|}{ Truly dissolved fraction } \\
\hline & $\mathrm{CMU}$ & CWA & $\mathrm{TC}$ & $\mathrm{CMU}$ & CWA & $\mathrm{TC}$ \\
\hline $\mathrm{Cr}$ & $0.762^{\mathrm{a}}$ & $0.841^{\mathrm{a}}$ & $0.823^{\mathrm{a}}$ & $0.801^{\mathrm{a}}$ & $0.804^{\mathrm{a}}$ & $0.830^{\mathrm{a}}$ \\
\hline $\mathrm{Co}$ & $0.768^{\mathrm{a}}$ & $0.857^{\mathrm{a}}$ & $0.835^{\mathrm{a}}$ & $0.864^{\mathrm{a}}$ & $0.829^{\mathrm{a}}$ & $0.851^{\mathrm{a}}$ \\
\hline $\mathrm{Ni}$ & $0.800^{\mathrm{a}}$ & $0.807^{\mathrm{a}}$ & $0.867^{\mathrm{a}}$ & $0.752^{\mathrm{a}}$ & $0.845^{\mathrm{a}}$ & $0.825^{\mathrm{a}}$ \\
\hline $\mathrm{Zn}$ & $0.782^{\mathrm{a}}$ & $0.833^{\mathrm{a}}$ & $0.854^{\mathrm{a}}$ & $0.784^{\mathrm{a}}$ & $0.793^{\mathrm{a}}$ & $0.802^{\mathrm{a}}$ \\
\hline $\mathrm{Cu}$ & $0.843^{\mathrm{a}}$ & $0.811^{\mathrm{a}}$ & $0.860^{\mathrm{a}}$ & $0.759^{\mathrm{a}}$ & $0.846^{\mathrm{a}}$ & $0.831^{\mathrm{a}}$ \\
\hline Mo & $0.813^{\mathrm{a}}$ & $0.812^{\mathrm{a}}$ & $0.850^{\mathrm{a}}$ & $0.787^{\mathrm{a}}$ & $0.844^{\mathrm{a}}$ & $0.919^{\mathrm{a}}$ \\
\hline $\mathrm{Cd}$ & $0.904^{\mathrm{a}}$ & $0.842^{\mathrm{a}}$ & $0.858^{\mathrm{a}}$ & $0.812^{\mathrm{a}}$ & $0.846^{\mathrm{a}}$ & $0.875^{\mathrm{a}}$ \\
\hline $\mathrm{Pb}$ & $0.735^{\mathrm{a}}$ & $0.767^{\mathrm{a}}$ & $0.827^{\mathrm{a}}$ & $0.734^{\mathrm{a}}$ & $0.772^{\mathrm{a}}$ & $0.746^{\mathrm{a}}$ \\
\hline
\end{tabular}

$\mathrm{CMU}=$ cross-membrane uptake.

$\mathrm{CWA}=$ cell wall adsorption .

$\mathrm{TC}=$ total concentration in intact roots.

${ }^{\text {a }}$ Significant at 0.05 probability level.

Table 4

Correlation coefficients $(R)$ of heavy metals in soil fractions $(n=15)$ with that in plant roots using BCR extraction procedure

\begin{tabular}{|c|c|c|c|c|c|c|}
\hline & \multicolumn{3}{|c|}{ B1 fraction } & \multicolumn{3}{|c|}{ B2 fraction } \\
\hline & $\mathrm{CMU}$ & CWA & $\mathrm{TC}$ & $\mathrm{CMU}$ & CWA & $\mathrm{TC}$ \\
\hline $\mathrm{Cr}$ & $0.653^{\mathrm{a}}$ & -0.11 & $0.489^{b}$ & 0.27 & 0.188 & $0.612^{\mathrm{a}}$ \\
\hline $\mathrm{Co}$ & $0.748^{\mathrm{a}}$ & 0.103 & $0.707^{\mathrm{a}}$ & 0.022 & -0.317 & 0.072 \\
\hline $\mathrm{Ni}$ & $0.477^{\mathrm{b}}$ & -0.344 & $0.552^{\mathrm{a}}$ & $0.547^{\mathrm{a}}$ & -0.381 & 0.348 \\
\hline $\mathrm{Zn}$ & $0.635^{\mathrm{a}}$ & 0.25 & $0.553^{\mathrm{a}}$ & 0.094 & 0.136 & 0.127 \\
\hline $\mathrm{Cu}$ & $0.683^{\mathrm{a}}$ & 0.43 & $0.694^{\mathrm{a}}$ & $0.470^{\mathrm{b}}$ & 0.344 & $0.525^{\mathrm{b}}$ \\
\hline Mo & 0.363 & 0.037 & $0.479^{\mathrm{b}}$ & 0.014 & 0.004 & 0.096 \\
\hline $\mathrm{Cd}$ & $0.678^{a}$ & $0.495^{\mathrm{b}}$ & $0.760^{\mathrm{a}}$ & $0.472^{\mathrm{b}}$ & 0.393 & $0.677^{\mathrm{a}}$ \\
\hline $\mathrm{Pb}$ & 0.323 & $0.503^{b}$ & $0.493^{\mathrm{b}}$ & 0.371 & $0.725^{\mathrm{a}}$ & $0.695^{\mathrm{a}}$ \\
\hline
\end{tabular}

$\mathrm{CMU}=$ cross-membrane uptake.

$\mathrm{CWA}=$ cell wall adsorption.

$\mathrm{TC}=$ total concentration in intact roots.

${ }^{\text {a }}$ Significant at 0.05 probability level.

${ }^{\mathrm{b}}$ Significant at 0.10 probability level. 
Table 5

Correlation coefficients for heavy metals in soil fractions $(n=15)$ and maize leaves

\begin{tabular}{llllc}
\hline & Soil colloidal fraction $^{\mathrm{a}}$ & Truly dissolved fraction $^{\mathrm{a}}$ & B1 fraction & B2 fraction \\
\hline $\mathrm{Cr}$ & $0.654^{\mathrm{b}}$ & $0.686^{\mathrm{b}}$ & $0.677^{\mathrm{b}}$ & 0.262 \\
$\mathrm{Co}$ & $0.597^{\mathrm{b}}$ & $0.663^{\mathrm{b}}$ & $0.618^{\mathrm{b}}$ & 0.040 \\
$\mathrm{Ni}$ & $0.555^{\mathrm{b}}$ & $0.643^{\mathrm{b}}$ & $0.469^{\mathrm{c}}$ & 0.184 \\
$\mathrm{Zn}$ & $0.519^{\mathrm{c}}$ & $0.595^{\mathrm{b}}$ & $0.498^{\mathrm{c}}$ & -0.004 \\
$\mathrm{Cu}$ & $0.576^{\mathrm{b}}$ & 0.394 & $0.731^{\mathrm{b}}$ & $0.466^{\mathrm{c}}$ \\
$\mathrm{Mo}$ & $0.657^{\mathrm{b}}$ & $0.851^{\mathrm{b}}$ & 0.485 & $0.544^{\mathrm{b}}$ \\
$\mathrm{Cd}$ & $0.830^{\mathrm{b}}$ & $0.848^{\mathrm{b}}$ & $0.737^{\mathrm{b}}$ & $0.695^{\mathrm{b}}$ \\
$\mathrm{Pb}$ & 0.324 & $0.570^{\mathrm{b}}$ & 0.462 & 0.309 \\
\hline
\end{tabular}

${ }^{\mathrm{a}}$ LMWOAs used as extractant.

${ }^{\mathrm{b}}$ Significant at 0.05 probability level.

${ }^{\mathrm{c}}$ Significant at 0.10 probability level.

between them from the point of view of statistics. Considering the small difference between the correlation coefficients of cell wall adsorption and cross-membrane uptake of heavy metals one might conclude that the cell wall adsorption and cross-membrane uptake were simultaneously accounted for the bioavailability. A good relationship between the concentrations of heavy metals in intact roots and that in soil supported this conclusion further. If compare the correlation coefficients between the heavy metals in soil colloid fraction and truly dissolved fraction it may beyond the expectation that no better correlation coefficients were obtained by using truly dissolved fraction. The reasons for this were obscure, however, the differences between the concentrations of heavy metals in soil colloidal fraction and in truly dissolved fraction could not reflected in the corresponding correlation coefficients.

If compare the correlation coefficients between the fractions B1 and B2 with cell wall, cross-membrane uptake and total concentration in intact roots it was easily found fraction B1 is bioavailable, however, the correlation coefficients were poor if compared with that obtained by LMWOAs. In addition, fraction B2 was not bioavailable by plants, which was reported previously (Li et al., 1998; Wang et al., 2001).

Correlation coefficients for heavy metals in soil fractions and in maize leaves are shown in Table 5. The results demonstrated that there was a poor relationship between the metal in fraction B2 and that in plants, and this phenomenon was often reported in the literature.

\section{Conclusion}

Based on the above study, the following conclusions can be drawn:

1. Wet rhizosphere soil and LMWOAs should be used for bioavailability test purpose, and in that case good correlation coefficients can be obtained. The extractable metal fractions by using BCR method are a poor indicator of bioavailability.

2. Heavy metals in soil solution can be partitioned between different colloidal fractions, and metals in truly dissolved fraction are easily available by plants. However, for practical purpose total metal concentrations in soil solution can be still used due to only insignificant difference between the correlation coefficients obtained by different colloidal fractions.

3. Heavy metals adsorbed by plant root cell wall and taken up by cross-membrane were rationally responsible for plant availability. Hereafter, total content in plants can be used for bioavailability because the differences between the correlation coefficients were negligible for cell wall adsorption and cross-membrane uptake.

4. The errors caused by fine soil grains adhered to plant roots should be considered and a suitable washing procedure should be taken in the case of necessary.

Generally, a mimic simulation of real-world field conditions, under which plants grow on soils, and the combined effects of soil-root interactions as a whole should be the direction of future study of bioavailablility.

\section{Acknowledgements}

This work was funded by the Chinese Academy of Science (Grant No. KZCX2-410) and National Natural Science Foundation of China (Grant No. 20177030 and 40171086).

\section{References}

Anderson, T.A., Guthrie, E.A., Walton, B.T., 1993. Bioremediation in the rhizosphere. Environ. Sci. Technol. 27, 26302636. 
Chen, B., Shan, X.Q., Qian, J., 1996. Bioavailability index for quantitative evaluation of plant availability of extractable soil trace elements. Plant Soil 186, 275-283.

Davies, B.E., 1992. Inter-relationship between soil properties and the uptake of cadmium, copper, lead and zinc from contaminated soils by radish (raphanus sativus L). Water Air Soil Pollut. 63, 331-342.

Houba, V.J.G., Lexmond, Th.M., Novozamsky, I., Van der Lee, J.J., 1996. State of the art and future developments in soil analysis for bioavailability assessment. Sci. Total Environ. 178, 21-28.

Howard, J.L., VandenBrink, W.J., 1999. Sequential extraction analysis of heavy metals in sediments of variable composition using nitrilotriacetic acid to counteract resorption. Environ. Pollut. 106, 285-292.

Jones, D.L., 1998. Organic acids in the rhizosphere- a critical review. Plant Soil 205, 25-44.

Kennedy, V.H., Sanchez, A.L., Oughton, D.H., Rowland, A.P., 1997. Use of single and sequential chemical extractants to assess radionuclide and heavy metal availability from soils for root uptake. Analyst 122, 89R-100R.

Kovacheva, P., Djingova, R., Kuleff, I., 2000. On the representative sampling of plants for multielement analysis. Phytol. Balcanica. 6, 91-102.

Krishnamurti, G.S.R., Naidu, R., 2002. Solid-solution speciation and phytoavailability of copper and zinc in soils. Environ. Sci. Technol. 36, 2645-2651.

Lao, J.S., 1988. Handbook for Soil Agriculture and Chemical Analysis. Agriculture Press, Beijing, China.

Lasat, M.M., Baker, A.J.M., Kochian, L.V., 1996. Physiological Characterization of root $\mathrm{Zn}^{2+}$ absorption and translocation to shoots in $\mathrm{Zn}$ hyperaccumulator and nonaccumulator species of Thlaspi. Plant Physiol. 112, 1715-1722.

Li, F.L., Shan, X.Q., Zhang, T.H., Zhang, S.Z., 1998. Evaluation of plant availability of rare earth elements in soils by chemical fractionation and multiple regression analysis. Environ. Pollut. 102, 269-277.

Li, Y.H., Huang, B.X., Shan, X.Q., 2003. Determination of low molecular weight organic acids in soils, plants, and water by capillary zone electrophoresis. Anal. Bioanal. Chem. 375, $775-780$.

López-Bucio, J., Nieto-Jacobo, M.F., Ramírez-Rodríguez, V., Herrera-Estrella, L., 2000. Organic acid metabolism in plants: from adaptive physiology to transgentic varieties for cultivation in extreme soils. Plant Sci. 160, 1-13.

Maiz, I., Esnaola, M.V., Millán, E., 1997. Evaluation of heavy metal availability in contaminated soils by a short sequential extraction procedure. Sci. Total Environ. 206, 107115.

Maria, G.E.S., Cogliatti, D.H., 1988. Bidirectional Zn-fluxes and compartmentation in wheat seeding roots. J. Plant Physiol. 132, 312-315.

Markert, B., 1993. Instrumentelle multielementanalyse von Pflanzenproben. VCH, Weinheim.

Markert, B., 1996. Instrumental Element and Multi-element Analysis of Plant Samples, Methods and Applications. John Wiley and Sons, New York.
McGrath, D., 1996. Application of single and sequential extraction procedures to polluted and unpolluted soils. Sci. Total Environ. 178, 37-44.

Novozamsky, I., Lexmond, Th.M., Houba, V.J.G., 1993. A single extraction procedure of soil for evaluation of uptake of some heavy metals by plants. Int. J Environ. Anal. Chem. $51,47-58$.

Qian, J., Wang, Z.J., Shan, X.Q., Tu, Q., Wen, B., Chen, B., 1996. Evaluation of plant availability of soil trace metals by chemical fractionation and multiple regression analysis. Environ. Pollut. 91, 309-315.

Sauvé, S., Cook, N., Hendershot, W.H., McBride, M.B., 1996. Linking plant tissue concentrations and soil copper pools in urban contaminated soils. Environ. Pollut. 94, 153157.

Sauvé, S., Norvell, W.A., McBride, M., Hendershot, W., 2000. Speciation and complexation of cadmium in extracted soil solutions. Environ. Sci. Technol. 34, 291-296.

Shan, X.Q., Chen, B., 1993. Evaluation of sequential extraction for speciation of trace metals in model soil containing natural minerals and humic acid. Anal. Chem. 65, 802807.

Shan, X.Q., Wang, Z.W., Wang, W.S., Zhang, S.Z., Wen, B., 2003. Labile rhizosphere soil solution fraction for prediction of bioavailability of heavy metals and rare earth elements to plants. Anal. Bioanal. Chem. 375, 400-407.

Tessier, A., Campbell, P.G.C., Bisson, M., 1979. Sequential extraction procedure for the speciation of particulate trace metals. Anal. Chem. 51, 844-851.

Tu, Q., Shan, X.Q., Qian, J., Ni, Z.M., 1994. Trace metal redistribution during extraction of model soils by acetic acid/sodium acetate. Anal. Chem. 66, 3552-3568.

Ure, A.M., Quevauviller, Ph., Muntau, H., Griepink, B., 1993. Speciation of heavy metals in soils and sediments. An account of the improvement and harmonization of extraction techniques undertaken under the auspices of the BCR of the Commission of the European Communities. Int. J. Environ. Anal. Chem. 51, 135-151.

Wang, Z.W., Shan, X.Q., Zhang, S.Z., 2001. Comparison of speciation and bioavailability of rare earth elements between wet rhizosphere soil and air-dried bulk soil. Anal. Chim. Acta. 441, 147-156.

Zhang, G., Taylor, G.J., 1989. Kinetics of aluminum uptake by excised roots of aluminum-tolerant and aluminum-sensitive cultivars of Troticum aestivum L. Plant Physiol. 91, 1094 1099.

Zhang, S.Z., Shan, X.Q., 1997. The determination of rare earth elements in soil by inductively coupled plasma mass spectrometry. At. Spectrosc. 18, 140-144.

Zhang, S.Z., Shan, X.Q., Li, F.L., 2000. Low-molecularweight-organic-acids as extractant to predict plant bioavailability of rare earth elements. Int. J. Anal. Chem. 76, 283-294.

Zhang, H., Zhao, F.J., Sun, B., Davison, W., McGrath, S.P., 2001. A new method to measure effective soil solution concentration predicts copper availability to plants. Environ. Sci. Technol. 35, 2602-2607. 